\title{
PERANAN FAKTOR USIA DALAM MEMODERASI PENGARUH PEMBERIAN INSENTIF TERHADAP MOTIVASI KERJA KARYAWAN KANTOR DIREKSI PT. PG. RAJAWALII SURABAYA
}

\author{
Hafiz Hermawan \\ Siti Sulasmi \\ Departemen manajemen Fakultas Ekonomi dan Bisnis Universitas Airlangga
}

\begin{abstract}
One of the company's efforts made in motivating employees is by giving rewards, such rewards are in the form of incentives. In order that these incentives can motivate employees, incentives given to companies can be either Monetary Incentive or Non-Monetary Incentives depending on how the appeal or the importance of the incentives for employees. But there are a few things to note companies, particularly with regard to the granting of incentives to boost employee motivation. Because in providing various forms of incentives to employees, the company needs to know the demographic characteristics of the employees as factors that can strengthen or weaken the relationship between incentives and employee motivation. One of the demographic characteristics of the form factor is the age of an employee, an employee who has a younger age it might be more motivated if the company gives incentives rather than a more senior employee. This is because a person's motivation in working for tend to be changed along with the increase of age. Employees with a younger age will likely pursue the monetary in the work, while employees who have senior will be more likely pursue the achievement of the monetary. Population and sample which became the object of this research is the 36 employees of PT. PG. Rajawali I. The results of the study prove that Monetary Incentives and Non Monetary Incentives give significant effects either simultaneously or partial employee motivation of PT. PG. Rajawali I. Whereas the moderation effect of age factor is not significantly strengthen the impact of influence the granting of providing Monetary Incentives and Non Monetary Incentives of employee motivation PT. PG. Rajawali I.
\end{abstract}

Keywords:Monetary Incentives and Non Monetary Incentives ;Employee Motivation.

\section{PENDAHULUAN}

Pengembangan sumber daya manusia secara makro adalah penting dalam rangka mencapai tujuan-tujuan pembangunan secara efektif. Demikian pula pengembangan sumber daya manusia secara mikro disuatu perusahaan sangat penting dalam mencapai hasil kerja yang optimal. Karena tujuan utama perusahaan pada umumnya adalah mencapai keuntungan dan berusaha untuk dapat bertahan dalam pasar persaingan pada jangka waktu yang panjang. 


\section{Hafiz Hermawan \\ Siti Sulasmi}

Untuk dapat mencapai tujuan tersebut maka perusahaan perlu untuk memaksimalkan kemampuan sumber daya manusia agar dapat bekerja secara maksimal. Sebagai pendorong sumber daya manusia untuk bekerja secara maksimal sesuai dengan tujuan perusahaan adalah motivasi. Motivasi kerja sangat penting bagi karyawan karena dengan motivasi kerja diharapkan individu karyawan mau bekerja keras dan antusias untuk mencapai produktivitas kerja yang tinggi. "Motivasi mempersoalkan bagaimana mendorong gairah kerja bawahan agar mereka mau bekerja keras dengan memberikan semua kemampuan dan keterampilanya untuk mewujudkan tujuan perusahaan" (Hasibuan, 2010:141).

PT. Rajawali I merupakan penggabungan Pabrik Gula Krebeł Baru dan Pabrik Gula Rejo Agung Baru yang merupakan anak perusahaan PT Rajawali Nusantara Indonesia. Penggabungan dua pabrik gula tersebut dilakukan di tahun 1995. Dalam menjalankan usahanya, kantor direksi PT Rajawali I sebagai kantor pusat berkedudukan di jalan Undaan Kulon, Surabaya-Jawa Timur. Sedangkan unit-unit dan anak perusahaan tersebar di wilayah Jawa Timur.

Sebagai perusahaan yang dinamis senantiasa memproyeksikan adanya pertumbuhan. Agar dapat mencapai angka pertumbuhan yang memadai, produk-produk yang dihasilkan harus memiliki daya saing. Untuk itu semua unit usaha telah melakukan berbagai upaya meningkatkan efisiensi dan produktifitas dengan tetap mengutamakan keunggulan kualitas produk yang dihasilkan serta peningkatan kualitas pelayanan menuju kepada pelayanan yang menggembirakan pelanggan.

\section{Tinjauan Pustaka}

\section{Motivasi Kerja}

Motivasi berasal dari kata latin movere yang berarti dorongan atau menggerakkan. Motivasi (motivation) dalam manajemen hanya ditujukan pada sumber daya manusia umumnya dan bawahan khususnya. Motivasi mempersoalkan bagaimana caranya mengarahkan daya dan potensi bawahan, agar mau bekerja sama secara produktif berhasil mencapai dan mewujudkan tujuan yang telah ditentukan. Berikut ini adalah pengertian-pengertian motivasi kerja menurut para ahli, diantaranya yaitu:

Pengertian motivasi kerja menurut Veithzal Rivai (2004:455) mengemukakan pernyataannya bahwa "Motivasi adalah serangkaian sikap dan nilai-nilai yang mempengaruhi individu untuk mencapai hal yang spesifik sesuai tujuan individu".

Pendapat lain mengenai definisi motivasi kerja menurut M. Manulang (2004:194) mengemukakan bahwa:

"Motivasi merupakan pekerjaan yang dilakukan oleh seorang manajer memberikan inspirasi, semangat dan dorongan kepada orang lain, dalam hal ini karyawan untuk mengambil tindakan-tindakan pemberian dorongan ini bertujuan untuk menggiatkan orang-orang 
karyawan agar mereka bersemangat dan dapat mencapai hasil sebagaimana dikehendaki dari orang-orang tersebut".

Sedangkan pendapat lain tentang motivasi kerja menurut Ernest J. Mc Cormick (1985:286) yang dikutip oleh A. Anwar Prabu Mangkunegara (2007:94) bahwa motivasi adalah "Motivasi adalah kondisi yang berpengaruh membangkitkan, mengarahkan dan memelihara perilaku yang berpengaruh dengan lingkungan kerja".

Dari pengertian diatas dapat disimpulkan bahwa motivasi kerja merupakan suatu keahlian dalam mengarahkan atau mengendalikan dan menggerakan seseorang untuk melakukan tindakan akan perilaku yang diinginkan berdasarkan sasaran-sasaran yang sudah ditetapkan untuk mencapai tujuan tertentu.

\section{Insentif}

Menurut Heidjrachman dan Suad Husnan, mengatakan sebagai berikut "Pengupahan insentif dimaksudkan untuk memberikan upah atau gaji yang berbeda karena beberapa prestasi kerja, guna meningkatkan produktivitas karyawan dan mempertahankan karyawan yang berbeda prestasinya untuk tetap berada dalam perusahaan".

Menurut Sarwoto, bahwa "Insentif merupakan suatu sarana motivasi dapat diberi batasan perangsang atau pendorong yang diberikan sengaja kepada para pekerja agar dalam diri mereka timbul semangat yang lebih besar untuk berprestasi bagi organisasi".

Menurut Gary Dessler yaitu: "Insentif finansial adalah ganjaran finansial yang diberikan kepada karyawan yang tingkat produksinya melampaui standar yang telah ditetapkan sebelumnya".

Menurut Moekijat, bahwa "insentif yang bentuknya sederhana adalah standard potongan yang menghubungkan pendapatan dengan produktifitas dan dapat menggunakan premi, bonus atau bermacam-macam standard untuk memberikan imbalan jasa kepada pelaksanaan pekerjaan yang lebih baik".

Dari pengertian insentif di atas, dapat disimpulkan bahwa insentif merupakan salah satu bentuk rangsangan yang sengaja diberikan oleh perusahaan kepada segenap pekerjanya agar para pekerja tersebut termotivasi dan mau bekerja dengan sungguh-sungguh sehingga tujuan perusahaan dapat tercapai.

\section{Insentif Material}

Meliputi beberapa sistem penghargaan berupa finansial yang diberikan dalam bentuk uang sebagai alat utama yang dapat membantu manusia dalam memenuhi kebutuhan pokok mereka. Dalam pemberian insentif ini terdapat perbedaan, hal ini disebabkan adanya tingkat atau golongan yang berbeda dari setiap karyawan dalam suatu perusahaan, berupa: 


\section{Hafiz Hermawan \\ Siti Sulasmi}

a) Bonus.Dibayarkan sebagai balas jasa atas hasil pekerjaan yang telah dilaksanakan. Dihitung dari persentase dari laba perusahaan yang melebihi jumlah tertentu dan dimasukkan ke dalam dana bonus dan kemudian diberikan kepada manajer dan karyawan.

b) Komisi . Merupakan sistem bonus yang dibayarkan kepada pihak yang menghasilkan penjualan yang baik. Lazimnya dibayarkan sebagai bagian dari penjualan dan diberikan kepada karyawan penjualan.

c) Profit Sharing. Biasanya mencakup pembayaran berupa sebagian dari laba bersih yang disetorkan ke dalam sebuah dana dan kemudian dimasukkan ke dalam daftar pendapatan peserta.

d) Penbayaran Yang Ditangguhkan. Merupakan jenis pembayaran balas jasa yang mencakup pembayaran dikemudian hari terdiri dari:

- Bantuan Hari Tua. Secara umum akan dapat direalisir pada perusahaan yang kondisi keuangannya cukup kuat dengan masa depan yang baik.

- Pensiun.Pensiun ini dibiayai sendiri oleh karyawan, sewaktu karyawan tersebut masih aktif bekerja. Dana pensiun diperoleh dengan memotong gaji karyawan tiap bulan sewaktu karyawan tersebut masih aktif bekerja.

- Pembayaran Kontraktual.Suatu pelaksanaan perjanjian antara majikan dengan pegawai, di mana pegawai yang selesai masa kerjanya dibayar dengan jumlah vang selama periode tertentu.

\section{Insentif Non Material}

Suatu Ganjaran bagi para karyawan yang bukan berbentuk keuangan, dalam hal ini merupakan kebutuhan karyawan yang bukan berwujud uang seperti :

1. Terjamin kenyamanan tempat kerja.

2. Terjaminnya komunikasi yang baik antara atasan dan bawahan.

3. Adanya penghargaan berupa pujian atau pengakuan atas kerja yang baik.

4. Tersedianya hiburan, pendidikan dan latihan.

5. Pemberian tanda jasa atau medali.

6. Ucapan terima kasih, baik secara formal maupun informal.

7. Pemberian promosi (kenaikan pangkat atau jabatan).

8. Pemberian perlengkapan khusus pada kerja (meja rapat, permadani dan lain-lain).

\section{Kerangka Berpikir}

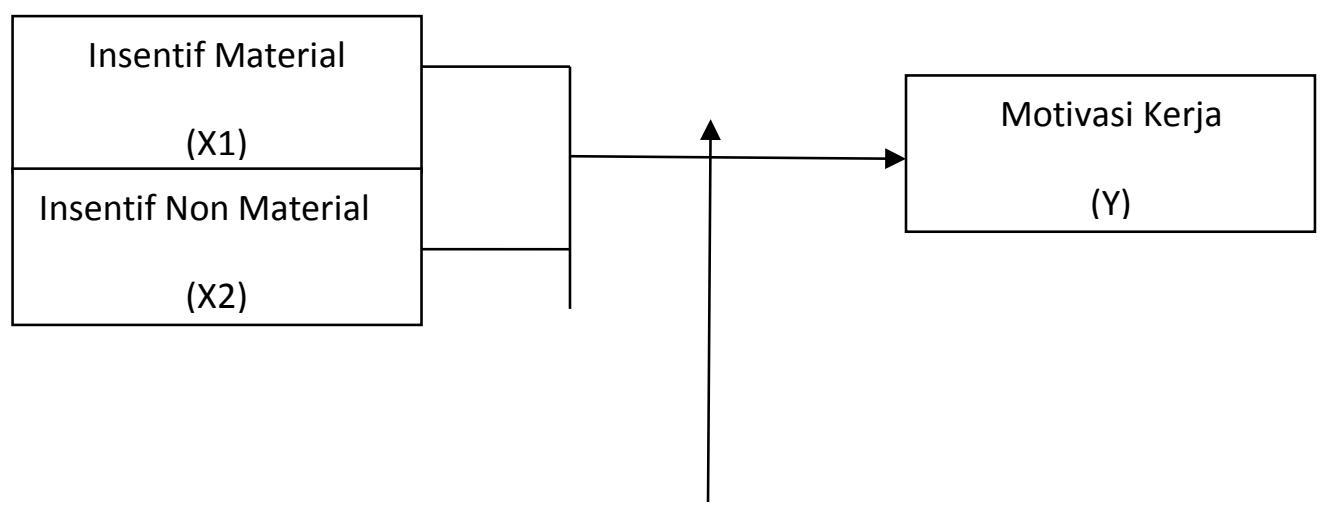




\section{Hipotesis}

Faktor Usia Karyawan

Hipotesis yang akan diteliti dalam penellitan Inı adalah:

H1 : Pemberian Insentif Material dan Non Materialmemberikan pengaruh signifikan secara simultan dan parsial terhadap motivasi kerja karyawan PT. PG. Rajawali I

H2: $\quad$ Faktor usia karyawan dapat menguatkan pengaruh pemberian Insentif Material dan Non Material secara simultan dan parsial terhadap motivasi kerja karyawan PT. PG. Rajawali I.

\section{Metode Penelitian}

Pendekatan penelitian ini dengan pendekatan kuantitatif dimana variabel-variabel yang diamati dapat diidentifikasikan dan hubungan antar variabel dapat diukur Data yang dikumpulkan adalah data primer dan sekunder melalui pengamatan langsurng, penyebaran kuisioner, dan riset kepustakaan sesuai dengan kebutuhan dalam penelitian ini.

Metode yang digunakan dalam penentuan sampel adalah metode sensus dimana seluruh jumlah populasi dijadikan sampel penelitian. Dalam penelitian jumlah sampel sebanyak 36 orang yang merupakan karyawan kantor direksi PT. PG. Rajawali I Surabaya.

Definisi operasional dari masing - masing variabel dalam penelitian ini adalah sebagai berikut :

1. Variabel bebas

Variabel bebas $\left(\mathrm{X}_{1}\right)$ :Insentif Material

Insentif ini meliputi sistem penghargaan berupa finansial yang memungkinkan karyawan menambah hasilnya dengan meningkatkan produktivitas kerja. Perbedaan dalam melaksanakan pemberian insentif ini disebabkan adanya tingkat atau golongan yang berbeda dari setiap karyawan.

Insentif Material berupa vang, dikarenakan uang adalah alat utama yang dapat memotivasi semangat kerja karyawan dalam melakukannya kegiatannya sehari-hari.

Indikator untuk mengukur variabel insentif material (X1), meliputi :

1.Bonus. Berupa vang yang dibayarkan sebagai balas jasa atas hasil pekerjaan yang telah dilaksanakan.

2.Komisi. Merupakan sejenis bonus yang akan dibayarkan kepada pihak bagian penjualan yang menghasilkan penjualan yang melebihi target.

3.Profit Sharing. Dalam hal pembayarannya dapat diikuti bermacam-macam pola, tetapi biasanya mencakup pembayarannya, berupa sebagian dari laba hasil yang disetorkan ke dalam setiap peserta. 


\section{Hafiz Hermawan \\ Siti Sulasmi}

4.Kompensasi yang Ditangguhkan. Merupakan jenis pembayaran balas jasa yang mencakup pembayaran dikemudian hari terdiri dari:

- Pensiun. Di Indonesia program ini sebagian besar diberlakukan untuk para pegawai negeri di mana perusahaan memotong gaji setiap bulannya pada saat karyawan tersebut masih aktif bekerja.

- Pembayaran Kontraktual. Suatu pelaksanaan perjanjian antara pimpinan dan pegawai, di mana pegawai setelah selesai masa kerja dibayarkan seumlah vang tertentu selama periode waktu tertentu.

- Jaminan Sosial. Lazimnya diberikan secara kolektif, tidak ada unsur kompetitif dan setiap karyawan dapat memperolehnya secara rata dan otomatis. Bentuknya antara lain : Pemberian rumah dinas, pengobatan secara Cuma-Cuma, pemberian kredit kepada pekerjaan atas barang-barang yang dibelinya dari kopersasi perusahaan, cuti sakit dengan tetap mendapatkan pembayaran gaji, pemberian status belajar, dan lain-lain.

Variabel bebas $\left(\mathrm{X}_{2}\right)=$ Insentif Non Material

Suatu Ganjaran bagi para karyawan yang bukan berbentuk keuangan, dalam hal ini merupakan kebutuhan karyawan yang bukan berwujud uang.

Indikator untuk mengukur variabel insentif non material (X2), meliputi :

1. Terjamin kenyamanan tempat kerja.

2. Terjaminnya komunikasi yang baik antara atasan dan bawahan.

3. Adanya penghargaan berupa pujian atau pengakuan atas kerja yang baik.

4. Tersedianya hiburan, pendidikan dan latihan.

5. Pemberian tanda jasa atau medali.

6. Ucapan terima kasih, baik secara formal maupun informal.

7. Pemberian promosi (kenaikan pangkat atau jabatan).

8. Pemberian perlengkapan khusus pada kerja (meja rapat, permadani dan lain-lain).

Variabel bebas (Z) = Faktor Usia Karyawan

Dalam penelitian ini faktor usia karyawan digunakan sebagai variabel moderator yang memberikan pengaruh pada hubungan antara pemberian insentif terhadap motivasi kerja karyawan. Hal ini untuk membuktikan apakah semakin tinggi usia seorang karyawan berpengaruh signifikan pada pemberian insentif baik material maupun non-material terhadap motivasi kerja karyawan.

2. Variabel terikat

Variabel terikat $(Y)=$ Motivasi Kerja

Motivasi kerja menurut pendapat yang dikemukakan oleh M. Manulang (2004:194), bahwa: 
"Motivasi merupakan pekerjaan yang dilakukan oleh seorang manajer memberikan inspirasi, semangat dan dorongan kepada orang lain, dalam hal ini karyawan untuk mengambil tindakan-tindakan pemberian dorongan ini bertujuan untuk menggiatkan orang-orang karyawan agar mereka bersemangat dan dapat mencapai hasil sebagaimana dikehendaki dari orang-orang tersebut".

Indikator untuk mengukur tingkat motivasi kerja karyawan (variabel Y), meliputi:

1. Tingkat kepuasan kerja karyawan.

2. Tingkat produktivitas kerja karyawan.

3. Tingkat kedisiplinan karyawan.

4. Loyalitas, kreativitas, dan tingkat partisipasi karyawan.

5. Tingkat kesejahteraan karyawan.

6. Rasa tanggung jawab karyawan terhadap tugas yang diberikan atasan.

\section{Prosedur}

Kuisioner penelitian peranan faktor usia dalam memberikan dampak pada pengaruh pemberian insentif terhadap motivasi kerja karyawan, diberikan kepada 36 karyawan kantor direksi PT. PG. Rajawali I Surabaya. Identitas karyawan pada kuisioner penelitian dijaga kerahasiaannya untuk menjaga hasil tidak terjadi subyektivitas. Data dari hasil kuisioner diolah menggunakan SPPS 13.0.

\section{ANALISIS DATA}

Tabel 4.1. Karakteristik responden

\begin{tabular}{|c|c|c|}
\hline Usia & Frekuensi & Persentase \\
\hline$<30$ Th & 3 & 8 \\
\hline $30-40$ Th & 10 & 28 \\
\hline $41-50$ Th & 13 & 36 \\
\hline$>50$ Th & 10 & 28 \\
\hline Total & 36 & 100 \\
\hline
\end{tabular}

Sumber : Lampiran 3

Berdasarkan Tabel 4.1 di atas dapat diketahui bahwa karyawan kantor direksi PT. PG. Rajawali I dengan usia di bawah 30 tahun yaitu sebanyak 3 orang (8\%), karyawan dengan usia antara 41-50 tahun yaitu sebanyak 13 orang (36\%), serta karyawan dengan usia antara 30-40 tahun dan di atas 50 tahun masing-masing sebanyak 10 orang $(28 \%)$, sehingga dapat disimpulkan bahwa mayoritas karyawan kantor direksi PT. PG. Rajawali I adalah berusia antara 41-50 tahun.

Berikut ini disajikan diagram pie chart untuk memberikan visualisasi proporsi karyawan kantor direksi PT. PG. Rajawali I berdasarkan usia: 


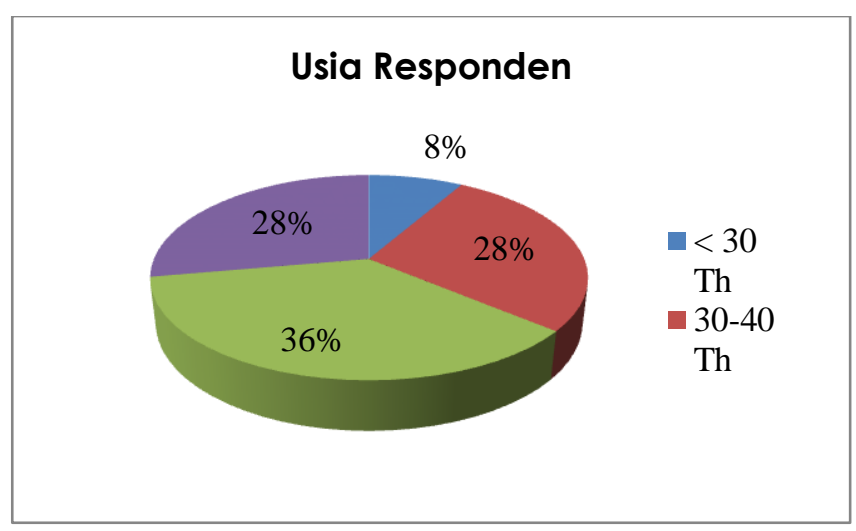

Tabel 4.8

Hasil Analisis Regresi

\begin{tabular}{|c|c|c|c|c|c|}
\hline Regresi & Variabel Bebas & Koefisien & $\begin{array}{l}\text { Signifikansi } \\
\text { † hitung }\end{array}$ & $\begin{array}{c}\text { Signifikansi } \\
\mathrm{F}\end{array}$ & $\mathrm{R}^{2}$ \\
\hline \multirow{3}{*}{1} & Konstanta & 0.013 & 0.977 & \multirow{3}{*}{0.000} & \multirow{3}{*}{0.698} \\
\hline & Insentif Material (X1) & 0.622 & 0.001 & & \\
\hline & Insentif Non-Material (X2) & 0.420 & 0.014 & & \\
\hline \multirow{7}{*}{ II } & Konstanta & 3.954 & 0.000 & \multirow{7}{*}{0.000} & \multirow{7}{*}{0.709} \\
\hline & Insentif Material (X1) & 0.341 & 0.011 & & \\
\hline & Insentif Non-Material (X2) & 0.242 & 0.037 & & \\
\hline & Usia (Z) & 0.067 & 0.471 & & \\
\hline & $\mathrm{X} 1 * \mathrm{X} 2$ & -0.134 & 0.429 & & \\
\hline & $\mathrm{X} 1 * \mathrm{Z}$ & 0.016 & 0.922 & & \\
\hline & $\mathrm{X} 2 * \mathrm{Z}$ & 0.086 & 0.521 & & \\
\hline \multicolumn{4}{|c|}{ Variabel Terikat: Motivasi Kerja (Y) } & & \\
\hline
\end{tabular}

Sumber. Lampiran 4

Berdasarkan Tabel 4.8, model persamaan regresi yang dihasilkan pada penelitian ini adalah:

Regresi I $: Y=0.013+0.622 \times 1+0.420 \times 2$

Regresi II : $Y=3.954+0.341 \times 1+0.242 \times 2+0.067 Z-0.134 X 1 * X 2+$

$$
0.016 \times 1 * Z+0.086 \times 2 * Z
$$

Berdasarkan Tabel 4.8 dapat diketahui bahwa koefisien regresi I untuk variabel Insentif Material (X1) dan Insentif Non-Material (X2) masing-masing bernilai positif sebesar 0.622 dan 0.420. Arah koefisien positif tersebut menunjukkan bahwa Insentif Material dan Insentif NonMaterial memiliki hubungan yang searah dengan Motivasi Kerja karyawan, dengan kata lain jika insentif yang diberikan perusahaan baik itu material dan non-material semakin baik, maka motivasi kerja karyawan akan semakin meningkat. Nilai Signifikansi uji † yang dihasilkan 


\section{Jurnal Manajemen Teori dan Terapan \\ Tahun 7. No.2, Agustus 2014}

yaitu sebesar 0.001 untuk Insentif Material dan 0.014 untuk Insentif Non-Material, dimana nilainilai tersebut lebih kecil dari $0.05(a=5 \%)$, sehingga dari hasil ini dapat disimpulkan bahwa masing-masing variabel bebas pada regresi I, yaitu Insentif Material dan Insentif Non-Material secara parsial berpengaruh signifikan terhadap Motivasi Kerja karyawan. Nilai signifikansi uji $f$ yang dihasilkan pada regresi I adalah sebesar 0.000 atau lebih kecil dari 0.05 ( $a=5 \%$ ), sehingga dapat disimpulkan bahwa secara simultan pemberian Insentif Material dan NonMaterial memiliki pengaruh signifikan terhadap motivasi kerja karyawan. Secara umum dari hasil regresi I, hipotesis pertama dari penelitian yang menyebutkan bahwa pemberian Insentif Material dan Non Material memberikan pengaruh signifikan secara simultan dan parsial terhadap motivasi kerja karyawan di kantor direksi PT. PG. Rajawali I dapat diterima kebenarannya. Pada regresi II dapat diketahui bahwa efek moderasi dari Usia (Z) pada hubungan antara pemberian Insentif Material terhadap Motivasi Kerja memiliki koefisien yang positif yaitu sebesar 0.016 dengan nilai signifikansi sebesar 0.922 atau di atas 0.05 $(a=5 \%)$, hal ini menunjukkan bahwa pengaruh moderasi dari usia pada hubungan antara pemberian Insentif Material terhadap Motivasi Kerja bersifat menguatkan namun tidak signifikan secara statistik. Hal serupa juga terjadi pada efek moderasi Usia pada hubungan antara pemberian Insentif Non-Material terhadap Motivasi Kerja menunjukkan sifat moderasi yang menguatkan dengan koefisien sebesar 0.086. Nilai signifikansi yang dihasilkan sebesar 0.521 atau di atas 0.05 ( $a=5 \%$ ), hal ini menunjukkan bahwa pengaruh moderasi dari usia pada hubungan antara pemberian Insentif Non-Material terhadap Motivasi Kerja bersifat tidak signifikan. Dengan kata lain bahwa hipotesis kedua dari penelitian yang menyebutkan bahwa faktor usia karyawan dapat menguatkan pengaruh pemberian Insentif Material dan Non Material secara simultan dan parsial terhadap motivasi kerja karyawan PT. Rajawali I tidak dapat diterima kebenarannya.

\section{Koefisien Determinasi}

Nilai R Square regresi I sebesar 0.698 menunjukkan bahwa pengaruh pemberian Insentif Material dan Non-Material terhadap tingkat motivasi kerja karyawan di kantor direksi PT. PG. Rajawali I adalah sebesar $69.8 \%$, sedangkan sisanya yaitu $30.2 \%$ dipengaruhi oleh variabel lain selain Insentif Material dan Non-Material. Nilai R Square regresi II sebesar 0.709 menunjukkan bahwa pengaruh pemberian Insentif Material, Insentif Non-Material serta efek moderasi usia terhadap tingkat motivasi kerja karyawan adalah sebesar $70.9 \%$, sedangkan sisanya yaitu $29.1 \%$ dipengaruhi oleh variabel lain di luar variabel Insentif Material, Insentif Non-Material serta efek moderasi dari usia. 


\section{PEMBAHASAN}

\section{Pembahasan Hipotesis Pertama}

Hipotesis pertama menyatakan bahwa pemberian Insentif Material dan Insentif Non-Material memberikan pengaruh signifikan secara simultan dan parsial terhadap motivasi kerja karyawan di kantor direksi PT. PG. Rajawali I. Hal ini dapat dijelaskan dengan koefisien regresi I yang menunjukkan masing-masing variabel bebas bernilai positif, yaitu variabel Insentif Material (X1) sebesar 0.622 dan variabel Insentif Non-Material (X2) sebesar 0.420. Arah koefisien positif tersebut menunjukkan bahwa Insentif Material dan Insentif Non-Material memiliki hubungan yang searah dengan Motivasi Kerja karyawan, dengan kata lain jika insentif yang diberikan perusahaan baik Insentif Material maupun Insentif Non-Material semakin baik, maka motivasi kerja karyawan akan semakin meningkat. Nilai signifikansi uji † yang dihasilkan yaitu sebesar 0.001 untuk Insentif Material dan 0.014 untuk Insentif NonMaterial, dimana nilai-nilai tersebut lebih kecil dari $0.05(a=5 \%)$, sehingga dari hasil ini dapat disimpulkan bahwa masing-masing variabel bebas pada regresi I yaitu Insentif Material dan Insentif Non-Material berpengaruh signifikan terhadap Motivasi Kerja karyawan.Nilai signifikansi uji f yang dihasilkan pada regresi I adalah sebesar 0.000 atau lebih kecil dari 0.05 ( $a=5 \%$ ), sehingga dapat disimpulkan bahwa secara simultan pemberian Insentif Material dan Insentif Non-Material memiliki pengaruh signifikan terhadap Motivasi Kerja karyawan.

\section{Pembahasan Hipotesis Kedua}

Pada pembahasan hipotesis kedua diketahui bahwa efek moderasi dari Usia (Z) pada hubungan antara Insentif Material terhadap Motivasi Kerja memiliki koefisien yang positif yaitu sebesar 0.016 dengan nilai signifikansi uji t sebesar 0.922 atau diatas $0.05(a=5 \%)$, hal ini menunjukkan bahwa pengaruh moderasi dari usia terhadap hubungan antara pemberian Insentif Material terhadap Motivasi Kerja bersifat menguatkan namun tidak signifikan secara statistik. Hal serupa juga terjadi pada efek moderasi Usia pada hubungan antara pemberian Insentif Non-Material terhadap Motivasi Kerja menunjukkan sifat moderasi yang menguatkan dengan koefisien sebesar 0.086. Dengan nilai signifikansi uji t sebesar 0.521 atau diatas 0.05 ( $a=5 \%$ ), maka hal ini menunjukkan bahwa pengaruh moderasi dari Usia pada hubungan antara pemberian Insentif Non-Material terhadap motivasi kerja bersifat tidak signifikan. Berdasarkan uraian diatas maka dapat disimpulkan bahwa hipotesis kedua yang menyebutkan bahwa Faktor Usia dapat menguatkan pengaruh pemberian Insentif Material dan Insentif Non-Material secara simultan dan parsial terhadap motivasi kerja karyawan tidak dapat diterima. Dikarenakan secara parsial tidak terdapat pengaruh yang signifikan moderasi Faktor Usia pada hubungan antara pemberian Insentif Material maupun Insentif Non-Material terhadap Motivasi Kerja karyawan 


\section{Jurnal Manajemen Teori dan Terapan \\ Tahun 7. No.2, Agustus 2014}

\section{Kesimpulan}

Berdasarkan hasil penelitian dan pembahasan tentang peranan faktor usia dalam memoderasi pengaruh pemberian insentif terhadap motivasi kerja karyawan kantor direksi PT. Pabrik Gula Rajawali I. Maka dapat diambil kesimpulan sebagai berikut :

1. Dari hasil penelitian diketahui bahwa koefisien regresi I untuk variabel Insentif Material sebesar 0.622 dan variabel Insentif Non-Material sebesar 0.420 . Hasil koefisien yang positif tersebut menunjukkan bahwa Insentif Material dan Insentif Non-Material memiliki hubungan yang searah dengan Motivasi Kerja karyawan. Artinya semakin baik Insentif Material dan Insentif Non-Material yang diberikan perusahaan maka Motivasi Kerja karyawan juga semakin meningkat.

2. Nilai dari signifikansi uji † yang dihasilkan yaitu 0.001 untuk Insentif Material dan 0.014 untuk Insentif Non-Material. Dari nilai signifikansi masing-masing variabel pada uji † tersebut yang lebih kecil dari 0.05 ( $a=5 \%)$, maka dapat disimpulkan bahwa secara parsial variabel Insentif Material dan Insentif Non-Material berpengaruh signifikan terhadap Motivasi Kerja karyawan.

3. Nilai signifikansi uji f yang dihasilkan pada regresi I adalah sebesar 0.000 atau lebih kecil dari 0.05 (a $=5 \%$ ), sehingga dapat disimpulkan bahwa secara simultan pemberian Insentif Material dan Insentif Non-Material memiliki pengaruh signifikan terhadap Motivasi Kerja karyawan.

4. Nilai R Square regresi I sebesar 0.698 menunjukkan bahwa pengaruh pemberian Insentif Material dan Insentif Non-Material terhadap tingkat Motivasi Kerja karyawan di kantor direksi PT. PG. Rajawali I adalah sebesar $69.8 \%$, sedangkan sisanya yaitu $30.2 \%$ dipengaruhi oleh variabel lain selain Insentif Material dan Insentif Non-Material.

5. Dari hasil regresi II diketahui bahwa efek moderasi Usia pada hubungan antara pemberian Insentif Material terhadap Motivasi Kerja memiliki koefisien yang positif yaitu sebesar 0.016 dengan nilai signifikansi uji † sebesar 0.922 atau diatas 0.05 (a $=5 \%$ ), hal ini menunjukkan bahwa pengaruh moderasi dari Usia pada hubungan antara pemberian Insentif Material terhadap Motivasi Kerja bersifat menguatkan namun secara statistik tidak signifikan. Hal serupa juga terjadi pada efek moderasi Usia pada hubungan antara pemberian Insentif Non-Material terhadap Motivasi Kerja menunjukkan sifat moderasi yang menguatkan dengan koefisien sebesar 0.086. Namun nilai signifikansi uji † yang dihasilkan sebesar 0.521 atau diatas $0.05(a=5 \%)$, hal ini menunjukkan bahwa pengaruh moderasi dari Usia pada hubungan antara pemberian Insentif Non-Material terhadap Motivasi Kerja bersifat tidak signifikan

6. Nilai R Square regresi II sebesar 0.709 menunjukkan bahwa pengaruh pemberian Insentif Material, Insentif Non-Material serta efek moderasi Usia terhadap tingkat Motivasi Kerja 


\section{Hafiz Hermawan \\ Siti Sulasmi}

karyawan adalah sebesar $70.9 \%$, sedangkan sisanya yaitu $29.1 \%$ dipengaruhi oleh variabel lain di luar variabel Insentif Material, Insentif Non-Material serta efek moderasi dari Usia.

\section{Saran}

Berdasarkan hasil penelitian dan simpulan dalam penelitian ini, maka dapat dikemukakan beberapa saran yang dapat disampaikan, sebagai berikut :

1. Secara umum Insentif Material yang diberikan sudah sesuai dengan apa yang diharapkan oleh karyawan. Akan tetapi terdapat persepsi terendah dari karyawan pada salah satu indikator Insentif Material, yaitu pada adanya sistem jaminan sosial yang diberikan perusahaan sesuai dengan gaji yang diperoleh karyawan. Hal ini menunjukkan adanya sedikit ketidakpuasan karyawan pada sistem pemberian jaminan sosial yang diberikan perusahaan. Jika perusahaan mampu meningkatkan persepsi karyawan pada sistem pemberian jaminan sosial maka kemungkinan karyawan untuk meningkatkan motivasi kerjanya juga akan semakin tinggi.

2. Sama seperti uraian diatas, juga terdapat persepsi terendah karyawan pada salah satu indikator Insentif Non-Material. Yaitu pada adanya penghargaan yang sifatnya tidak riil kepada karyawan yang telah menunjukkan dedikasinya terhadap perusahaan. Jika perusahaan mampu untuk merubah sifat yang lebih riil dari penghargaan yang diberikan kepada karyawan, maka kemungkinan besar karyawan juga akan meningkatkan motivasi kerjanya dan semakin menunjukkan dedikasinya terhadap perusahaan.

3. Pada indikator Motivasi Kerja terdapat persepsi terendah dari karyawan, yaitu berupa kemauan untuk bekerja sendiri tanpa bantuan rekan kerja. Meskipun secara keseluruhan variabel Motivasi Kerja memiliki nilai yang tinggi dalam arti sesuai dengan persepsi karyawan, akan tetapi jika perusahaan mampu menyelaraskan seluruh indikator yang ada pada variabel Motivasi Kerja maka tentu akan berdampak positif bagi kemajuan perusahaan. Terutama pada variabel yang mendapat persepsi terendah yang sudah saya uraikan diatas, yaitu merubah kondisi kerja yang memungkinkan karyawan untuk dapat bekerja sendiri tanpa bergantung pada bantuan rekan kerja. 


\section{DAFTAR PUSTAKA}

Daft, Richard L. 2002. Pengantar Manajemen. Edisi Kelima. Terjemahan. Jakarta: Penerbit Erlangga.

2008. The Leadership Experience. Fourth Edition. Oklahoma : South- Western.

Dessler, Gary. 2003. Manajemen Sumber Daya Manusia Edisi kesepuluh. Terjemahan Paramita Rahayu. Klaten : Intan Sejati.

Ernest J. McCormick, 1985, "Indutrial Psycology", New York, Prentice Hall, Inc.

Gibson, L.J., Ivancevich M.J, Donelly. 1997. Organisasi dan Manajemen: Perilaku, Struktur, Proses. Edisi Kelima. Terjemahan. Jakarta : Penerbit Erlangga.

Gomes, Faustino C. 2003. Manajemen Sumber Daya Manusia. Edisi Kedua. Yogyakarta : Andi Publisher.

Gujarati, Damodar. 2003. Ekonometrika Dasar : Edisi Keenam. Jakarta: Erlangga.

Hair, J.F., et al. 2010. Multivariate Data Analysis Edisi Ketujuh. New Jersey : Pearson Education Inc.

Handoko, Hani T. 2003. Manajemen. Yogyakarta. Penerbit: BPFE.

Hasibuan, H. Malayu SP. 2001. Manajemen Sumber Daya Manusia. Jakarta Penerbit: Bumi Aksara.

Heidjrachman Dan Husnan,Suad. 2002. Manajemen Personalia. Penerbit :BPFE UGM, Yogyakarta.

Madura, Jeff. 2001. Teori Organisasi . Jakarta : Penerbit Erlangga.

M. Manullang \& Marihot Manullang 2001. Manajemen Sumber Daya Manusia. Penerbit BPFE, Yogyakarta

Mangkunegara, Anwar Prabu AA. 2007. Manajemen Sumber Daya Manusia Perusahaan.

Bandung. Penerbit:PT. Remaja Rosdakarya.

Mangkunegara, Anwar Prabu AA. 2006. Perencanaan \& Pengembangan SDM. Bandung. Penerbit: PT. Refika Aditama.

Mangkuprawira, Syafri. 2003. Manajemen Sumber Daya Manusia Strategik. Bogor : Penerbit Ghalia Indonesia.

Marihot Tua Efendi Hariandja, Drs.,M.Si. 2002. Manajemen Sumber Daya Manusia. Jakarta: Grasindo

Marzuki, 1989, Metodolgi Riset, Penerbit BPFE, Yogyakarta.

Moekijat. 1999. Manajemen Sumber Daya Manusia. Bandung: CV. Mandar Maju. 
Hafiz Hermawan

Siti Sulasmi

Nandanwar M.V., Surnis S.V., Nandanwar L.M. 2010. Intervening factors affecting the relationship between incentives and employee motivation: a case study of pharmaceutical manufacturing organisation in Navi Mumbai. Journal of Business Excellence, ISSN: 0976-7711, Vol. 1, Issue 2, pp-06-11

Nazir, Moh. 2004. Metode Penelitian. Cetakan Keenam. Ciawi- Bogor Selatan : Penerbit Ghalia.

Robbins, Stephen P., 2003. Essential of Organizations. Seventh Edition. New Jersey : Prentice Hall.

-. 1993. Organizational Behavior. Sixth Edition. New Jersey : Prentice Hall.

2008. Perilaku Organisasi. Edisi Kedua Belas. Terjemahan. Jakarta : Penerbit Salemba Empat.

Ruky, Ahmad S. 2002. SDM Berkualitas Mengubah Visi Menjadi Realitas. Jakarta : Penerbit PT. Gramedia Pustaka Utama.

Sarwoto, 2000, Dasar-Dasar Organisasi dan Manajemen, Ghalia, Jakarta Indonesia

Singgih Santoso, 2001, SPSS versi 10, PT Elex Media Komputindo, Jakarta

Sugiyono. 2007. Statistika Untuk Penelitian. Bandung. Penerbit: CV. Alfabeta.

Sugiyono. 2004. Metode Penelitian Bisnis. Cetakan Keempat. Bandung : Penerbit Alfabeta. 2009. Metode Penelitian Bisnis. Cetakan Ketiga Belas. Bandung : Penerbit Alfabeta.

Sugiyono.2013. Metode Penelitian Pendidikan: Pendekatan Kuantitatif Kualitatif dan R \& D. Bandung: Alfabeta.

Sumarsono, Sonny. 2004. Metode Riset Sumber Daya Manusia. Edisi Pertama. Yogyakarta: Penerbit Graha llmu.

Sutarto. 1991. Dasar - dasar Organisasi. Yogyakarta : Gajah Mada University Press.

Suwatno. 2001. Asas-asas Manajemen Sumber Daya Manusia. Bandung: Suci Press.

Umar, Huusein.2013. Metode Penelitian untuk Skripsi dan Tesis Bisnis. Edisi kedua. Jakarta: Rajawali pers.

Veithzal Rivai 2005. Manajemen Sumber Daya Manusia Untuk Perusahaan. Penerbit PT. Raja Grafindo Persada, Jakarta.

Werther Jr, William B, Keith Davis. 1993. Managing Personalia. United States of Amerika : Mc Graw Hill Book Co. 